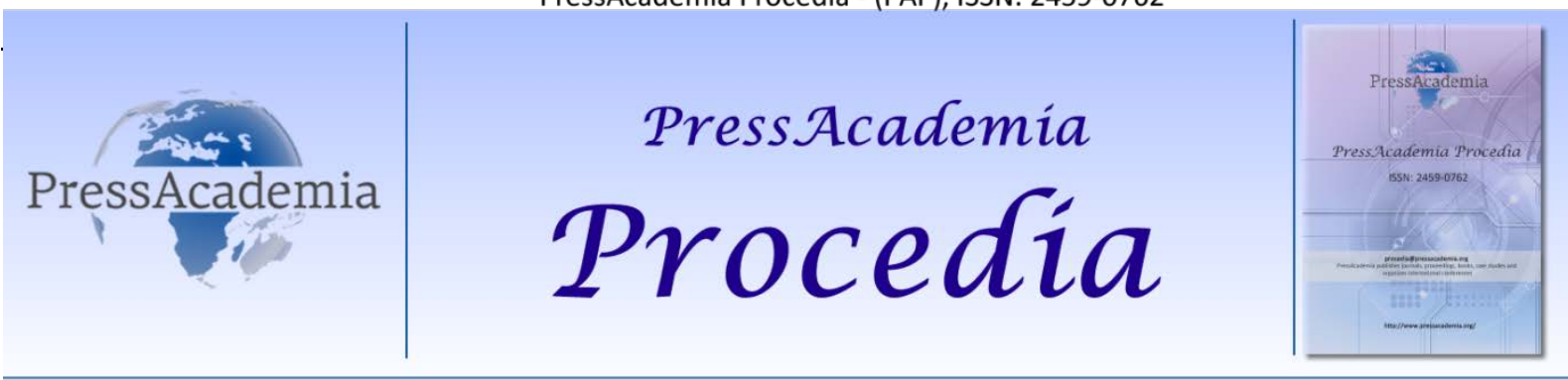

Global Business Research Congress (GBRC), May 26-27, 2016, Istanbul, Turkey.

\title{
DETERMINING THE RELATIONSHIP BETWEEN EMOTIONAL LABOUR AND OCCUPATIONAL COMMITMENT OF ACADEMICIANS
}

\section{DOI: 10.17261/Pressacademia.2016118635}

\author{
Ceren Giderler ${ }^{1}$, Hilal Durmus ${ }^{2}$, Canan Kirmizi ${ }^{3}$ \\ ${ }^{1}$ Dumlupınar Üniversitesi , ceren.gatalay@dpu.edu.tr \\ ²Dumlupınar Üniversitesi, hilal.durmus@dpu.edu.tr \\ ${ }^{3}$ Dumlupınar Üniversitesi, canan.kirmizi@dpu.edu.tr
}

\begin{abstract}
The main purpose of our study is to descibe the relationship between emotional labor behaviors and the occupational commitment of academicians. The concept of emotional labor on which researchers often emphasized in recent years, is important for a sector where employees is in close and intense relationship with their co-workers. It discussed the three dimensions of emotional labor in this study; surface, deep and sincere behaviors (Oral ve Köse, 2011: 472). The occupational commitment that is a psychological bond between the individual and the occupation were analyzed under three dimensions, including affective, normative and emotional commitment. Within the scope of the research, from 273 academicians who worked at five state universities in Turkey collected data through the online survey method was analyzed using SPSS 18 software. According to research results, while there is a negative relationship between surface behaviour that is dimensin of emotional labour and affective commitment, it has been found to have a positive relationship between surface behaviour and normative and continuance commitment. The dimension of the deep behavior was in a meaningful relationship with normative commitment. A relationship in a positive direction has been determined between sincere behaviour and affective commitment.
\end{abstract}

Keywords : Emotional labor, occupational commitment, scademicians

JEL Codes : M10, M19

\section{AKADEMISYENLERIN MESLEKI BAĞLILIKLARI ILE DUYGUSAL EMEK DAVRANIŞLARI ARASINDAKI iLIŞKININ BELIRLENMESI}

\section{ÖZET}

Çalışmamızın temel amacı, akademisyenlerin mesleki bağlııklarının, duygusal emek davranışları ile ilişkisini ortaya koymaktır. Son yıllarda araştırmacıların sıklıkla üzerinde durduğu duygusal emek kavramı, birebir ilişkinin yoğun olduğu sektör çalışanları için önem arz etmektedir. Bu çalışmada duygusal emeğin ele alınan üç alt boyutu; yüzeysel, derin ve samimi davranıştır (Oral ve Köse, 2011: 472). Birey ve mesleği arasındaki psikolojik bağ olan mesleki bağ|ılık ise, devam bağılığı, normatif bağlıık ve duygusal bağ|ılık olmak üzere üç boyut altında incelenmiştir. Araştırma kapsamında Türkiye'deki beş devlet üniversitesinde görev yapan 273 akademisyenden online anket yöntemiyle toplanan veriler SPSS 18 programında değerlendirilmiştir. Araştırma sonuçlarına göre duygusal emek boyutlarında yüzeysel davranış ile duygusal bağ|ııık arasında negatif bir ilişki varken, normatif bağ|ıık ve devam bağ|lığı ile pozitif ilişki içinde olduğu tespit edilmiştir. Derin davranış boyutu, sadece normatif bağlılık ile anlamlı bir ilişki içindeyken, samimi davranışın ise sadece duygusal bağlılık ile pozitif yönde bir ilişki içinde olduğu belirlenmiştir.

Anahtar Kelimeler: Duygusal emek, mesleki bağlılık, akademisyenler JEL Kodları: M10, M19 


\section{GiRiş}

İnsanlık tarihi kadar eski bir geçmişe sahip olan duygu olgusu, 1800'lü yıllarda araştırmaya başlanmıştır. Her ne kadar klasik örgüt yaklaşımının hüküm sürdüğü dönemlerde bireylerin duyguları göz ardı edilse de, günümüzde en çok ilgi gören ve çalışılan alan olarak karşımıza çıkmaktadır. Çünkü bireyler, örgütlerinde duygu, düşünce ve davranışları ile yekvücut olarak hizmet vermektedirler. Duyguların örgütlerdeki yeri ve önemi 1980'li yıllardan sonra çalışılmaya başlanmıştır.

Günümüz örgüt çalışmalarında dikkat çeken kavramlardan biri olan duygusal emek, Amerikalı Sosyolog Arlie Hochschild tarafından 1983'de "Yönetilen Kalp: İnsan Duygularının Ticarileştirilmesi” adlı eserini yayınlaması ile literatüre kazandırılmıştır. Duygusal emek, çalışanların müşterilerde olumlu bir izlenim oluşturabilmek ve onları memnun edebilmek için duygularını kontrol etmesi ve önceden belirlenmiş duygu kalıplarını müşterilerine sunmalarıdır (Hochschild, 1983:7).

Örgütler için duygusal emek kadar önemli bir diğer konu da mesleki bağlılıktır. Mesleki bağ|ılık, bireyin mesleğinin ne kadar merkezi bir yere sahip olduğunu ve hayatındaki önemini belirli bir alanda yetenek ve uzmanlık kazanmak için yaptığı çalışmalar sonucunda algılamasıdır (Özdevecioğlu ve Aktaş, 2007: 5). Bireyin mesleğine duyduğu bağlılığın iş yaşamına ve çalıştığı örgüte katkı sağlayacağı ve olumlu sonuçlar ortaya çıkaracağı düşünülmektedir. Bu sonuçlardan biri ise duygusal emektir.

Özellikle müşterileriyle yüz yüze iletişimle hizmet veren çalışanların duygusal emek gösterimleri daha fazladır. Bu nedenle duygusal emeğin en çok irdelendiği alan hizmet sektörüdür. Ancak toplumun geleceğini oluşturan en önemli kurumlardan biri olan üniversitelerin akademik personeli de hizmet sundukları öğrencileriyle yüz yüze etkileşim içinde olduklarından, duygusal emek gösteriminin incelenmesi gereken alanlardan biri de eğitim kurumlarıdır. Bu düşünce doğrultusunda, akademisyenlerin mesleklerine duydukları bağlılığın duygusal emek davranışlarını ne yönde etkilediği bu çalışma kapsamında incelenmeye çalışılmıştır.

\section{LITERATÜR TARAMASI}

Hizmet sektörünün hızlı büyümesiyle kişiye özel olan duygu, ekonomik değere sahip somut bir ürün haline gelmiştir. Bu nedenle duygusal emeğin birçok hizmet alanı ve meslek için temel bir bileşen haline geldiği görülmektedir (Özgen, 2010). Kavramı literatüre kazandıran Hochschild (1983)'e göre duygusal emek; çalışanın diğer kişiler tarafından gözlenecek olan duygularını işi gerektirdiği şekilde düzenlemesi ve buna eşdeğer yüzeysel ve bedensel davranışlarda bulunmasıdır. Bu kavram zaten duyguların sergilenmesi, yani gözlemlenebilir davranışlara dönüştürülmesini ifade etmektedir (Ashforth ve Humphrey, 1993:89).

Farklı yazarlar tarafından farklı şekillerde tanımlanan duygusal emek, Ashforth ve Humphrey (1993: 90)'e göre uygun duyguyu sergileme davranışıdır.

Hoschschild (2003)'e göre duygusal emek gerektiren işlerin belirli özellikleri vardır. Bunlar: insanlarla doğrudan temasın olması, çalışanların diğer kişilere karşı duygularını kullanmasını gerektirecek bir durumun olması ve çalışanların duyguları üzerinde kontrol imkanı veren işlerin olmasıdır (Başbuğ vd., 2010). Grandey (2000)'e göre ise duygusal emek, çalışanların kural ve normlara göre duygusal davranış göstermesinin zorunlu olduğu hizmet işletmeleri için gereklidir. Grandey'i destekler nitelikte Hoschschild (1983) de, kadın hakimiyetindeki işlerin yüksek oranda duygusal emek gerektirdiğini belirterek, bu işlerden bazılarının hemşirelik, öğretmenlik ve satış elemanlığı oluğunu belirtmiştir (Beğenirbaş ve Yalçın, 2012: 50).

Duygusal emeği daha iyi anlamak, türlerini ortaya koyabilmek için araştırmacılar tarafından çeşitli yaklaşımlar geliştirilmiştir. Bu konuda temel niteliğini taşıyan ve en sık kullanılan yaklaşım Hochschild (1983) tarafından ortaya konulmuştur. Hochschild (1983) duygusal emeği yüzeysel davranış (surface action) ve derin davranış (deep action) olarak iki alt boyutta incelemektedir. Yüzeysel davranışta, çalışanlar örgütün belirlediği duygusal davranış kuralları doğrultusunda gerçekte hissettikleri duyguları saklayarak ve bir anlamda örgütün istediği şekilde davranabilmek için duygularını sahteleştirerek karşısındaki alıcılara yansıtmaktadırlar (Hoschschild, 1983; Brotheridge ve Grandey, 2012). Örneğin, bir öğretmenin negatif bir ruh hali içindeyken dahi öğrencilerine karşı güler yüzlü davranması ya da bir tezgahtarın zor beğenen, kaprisli müşterisine sinirlendiğini belli etmeden güler yüzlü davranmaya devam etmesi birer yüzeysel davranış gösterimidir. Buradaki en önemli husus çalışanın gerçek 
duyguları, sergilediği duygulardan tamamen farkılık göstermektedir. Yani gerçek duygularını maskeleyerek dışarıya karşı farklı duygusal davranışlar sergilemektedir. (Grandey, 20003;46). i̇kinci boyut olan derin davranışta ise çalışanın kendisinden sergilenmesi beklenen davranışı bir aktör gibi etkileşimde bulunduğu bireylere gerçek duygularını hissettirmeden gerçekle birebir örtüşecek şekilde istenilen role bürünmesidir (Hochschild, 1983; Brotheridge ve Grandey, 2002). Örneğin, bir öğretmenin zor süreçler yaşayan öğrencisi ile empati kurması ve ona ilgili davranması gibi (Grandey, 2003: 87). Bu tanımlamaya göre derinlemesine davranışı yüzeysel davranıştan ayıran nokta derin davranışta çalışanın davranışları gibi duygularını da duygusal davranış kurallarına uyumlu hale getirmesi gerekmektedir (Oral ve Köse, 2011:473).

Ashforth ve Humprey (1993) tarafından yapılan çalışmalar ile çalışanın kendisinden beklenen davranışı, herhangi bir zorlama olmadan kendisi hissettiği için doğal olarak sergileyeceği düşünülerek duygusal emeğin üçüncü boyutu olan samimi (doğal) davranış literatüre kazandırımışıı (Diefendorff ve Gosserand,2003: 24). Samimi davranış, çalışanın sergilemek zorunda oldukları duygular ile gerçekte hissettikleri duyguların aynı olması durumunu ifade etmektedir (Kruml ve Geddes, 2000). Örneğin, bir öğretmenin başarılı bir öğrencisinin okuldan ayrılması durumu için yaşadığı üzüntü (Diefendorff ve Gosserand,2003: 24) , ya da bir içecek servis elemanının müşterisinin sıkıntılarını dinleyip, tavsiyelerde bulunması (Chu ve Murrman, 2006) samimi duygularının bir göstergesidir.

Literatür incelendiğinde duygusal emeğin farklı araştırmacılar tarafından farklı şekillerde boyutlandırıldığı görülmektedir. Ancak yaygın olarak kullanılan Hochschild (1983)'in geliştirdiği yüzeysel ve derin davranış ve Ashforth ve Humprey (1993)'in ilave ettiği samimi davranış boyutlarıdır. Bu çalışmada da duygusal emek yüzeysel, derin ve samimi davranış olmak üzere üç boyutta incelenecektir.

Meslek genel anlamda bireylerin hayatlarını devam ettirebilmek ve maddi anlamda gelir sağlamak üzere belirli bir süre bir işte çalışmaları olarak tanımlanmaktadır. (Lee vd., 2000: 800). Mesleki bağlıık ise, uzmanlık kazanmaya bağlı olarak değişen bireyin hayatta mesleğine verdiği önem derecesi olarak ifade edilebilmektedir. Bireyin mesleğine bağlılı̆ı belirli olan bir alanda uzmanlık ve beceri kazanmak için yaptığı çalışmaların nihayetinde mesleğini hayatında ne derece merkezde konumlandırdığı ile ilgilidir (Baysal ve Paksoy, 1999: 9).

Mesleki bağııığa ilişkin literatür incelendiğinde kavramın ilk kez 1971 yılında Greenhaus tarafından 'bireylerin bir kariyere ya da işe önem vermeleri' olarak ortaya atıldığı görülmektedir. Morrow (1983) tarafından geliştirilen iş̧ Bağıılığı Modeli ise, bugünkü anlamdaki mesleki bağlılık için temel referans kaynağı olarak kabul edilmektedir (Morrow, 1983:487; Morrow, 1993;21). Aynı zamanda mesleki bağlılığa ilişkin Aranya ve ark. (1981) tarafından geliştirilen teori, mesleki bağılık araştırmalarında en çok kullanılan önemli bir yaklaşımdır. Bu yaklaşıma göre mesleki bağlıık, belirli bir mesleğe bağlanma ve özdeşleşmenin derecesi şeklinde tanımlanmaktadır. Bu sebeple bu teoride mesleki bağlılık, mesleğin hedef ve değerlerine inanma ve kabul etme, mesleğin faydası için çaba sarfetmeye gönüllü olma ve son olarak meslek üyeliğini sürdürme konusunda ısrarlı olma şeklinde karakterize edilmiştir.

Araştırmacılara göre, profesyonel olan ya da olmayan bütün bireylerin iş hayatları boyunca mesleki bağlılık deneyimi geçirdikleri görülebilmektedir. Aynı zamanda kariyer ifadesinin de bireylerin çalışma hayatları boyunca tercih ettikleri farkı işleri, işlerine ilişkin faaliyetleri ve meslek tercihlerini kapsamasından ötürü kavramı tam olarak açıklayamamaktadır. Bu yüzden araştırmacılar mesleki bağııık ifadesinin kullanımı daha uygun görmüşler ve mesleki bağlılığı 'kişilerin meslekleri ile aralarında geliştirdikleri psikolojik ilişki ve mesleklerine karşı gösterdikleri duygusal tepki' olarak tanımlamışlardır (Meyer vd., 1993:539-540; Lee vd., 2000: 800).

Örgütsel bağlılı̆ı̆ üç boyut olarak ele alan Meyer ve Allen (1991), geliştirdikleri bu modelden faydalanarak mesleki bağ|ıı̆ı̆ın da çok boyut içeren bir yapıda olduğunu ifade ederek, bu boyutları normatif, duygusal ve devam bağılığı olmak üzere üçe ayırmışlardır. Illk boyutu olan duygusal mesleki bağlıık, kişilerin mesleklerinde kalmayı istemesini, meslekle özdeşleşmesini, mesleğini severek yaparak mesleğin değer ve amaçlarını kabullenebilmeyi ifade etmektedir (Meyer ve diğerleri, 1993; Meyer ve Allen, 1997; Lee ve diğerleri, 2000). Mesleki devam bağılığı ise, bireyin yeni bir meslek seçmek adına elinde uygun alternatiflerinin olmaması durumudur. Bu koşullarda birey mesleğini bırakmasının oluşturacağı duygusal bedelleri en hafif şekilde atlatabilmek için yeni iş seçeneklerini araştırmaktan vazgeçecektir (Çetin vd, 2010). Son boyut olan normatif mesleki bağlılık ise, bireylerin meslekte kalmayı bir zorunluluk, yükümlülük olarak görmesidir (Meyer vd., 1993). 


\section{VERI VE YÖNTEM}

Bireylerin mesleklerine karşı duydukları sevgi ve bağlılığın duygusal emek gösterim çabalarını pozitif yönde etkileyeceği ve bireylerin duygusal uyumsuzluk yaşamasını engelleyeceği düşünülmektedir. Bu doğrultuda, araştırmanın amacı, akademisyenlerin mesleki bağlııklarının duygusal emek davranışları üzerindeki etkisini ve yönünü belirlemeye çalışmaktır.

Çalışmanın ana kütlesini Türkiye'deki beş devlet üniversitesinde görev yapan akademisyenler oluşturmaktadır. Ana kütle olarak akademisyenlerin seçilmesinin sebebi, akademisyenlerin gerek çalışma arkadaşları gerekse öğrencilerle olan ilişkilerinde yoğun duygusal emek gösteriminde bulundukları ve bu çabanın ne kadarının mesleki bağlılıktan kaynaklandığını keşfetme düşüncesidir. Bu ana kütle içerisinden basit tesadüfî örnekleme yoluyla seçilen 273 akademisyen aştırmanın örneklemini oluşturmaktadır.

Araştırmayı nicel verilerle desteklemek amacıyla anket yöntemine başvurulmuştur. Bu amaçla, internet üzerinden online anket uygulaması yapılmıştır. 273 katılımcıdan elde edilen veriler SPSS 18 programı kullanılarak değerlendirilmiştir.

Araştırmada iki ayrı ölçek kullanılmıştır. Çalışmada kullanılan ölçeklerden ilki, Grandey'in (1999), Brotheridge ve Lee'nin (1998) çalışmasından yararlanarak geliştirdiği ve doktora tez çalışmasında kullandığı duygusal emek ölçeğidir. Ölçeğin Türkçeye uyarlanma çalışması Köksel (2009) tarafından yüksek lisans tezinde kullanmak amacıyla yapılmıştır. Bu çalışmada da Köksel (2009)'in kullanmış olduğu 26 ifadeden oluşan duygusal emek ölçeği kullanılmıştır. Çalışmada kullanılan ölçeklerden ikincisi ise Meyer ve diğerleri tarafından(1993) geliştirilmiş olan ve Tak ve Çiftçioğlu (2009) tarafından Türkçeye uyarlanan, üç boyutlu mesleki bağlılık ölçeği kullanılmıştır. Ölçek 18 ifadeden oluşmaktadır. Ölçekler beşli likert tipinde hazırlanmıştır.

Şekil 1: Araştırma Modeli

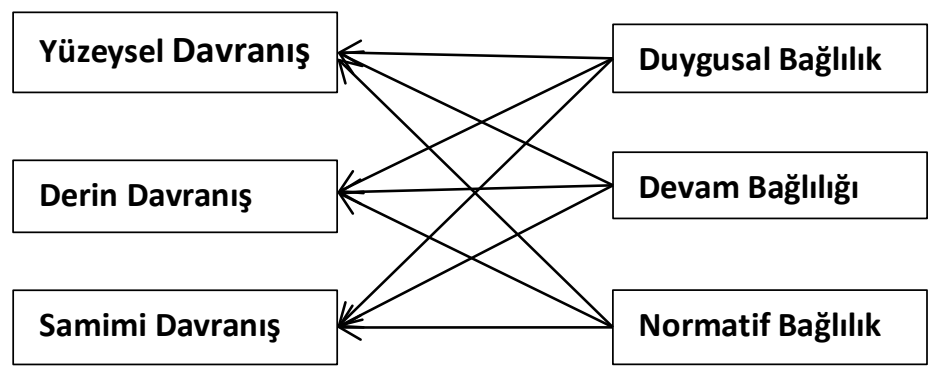

Çalışma kapsamında oluşturulan araştırma modeline ve test edilen hipotezlere bu başlık altında yer verilmiştir.

$\mathbf{H}_{1}$ : Mesleki bağııık boyutları yüzeysel davranışı pozitif yönde anlamlı olarak etkilemektedir.

$\mathbf{H}_{2}$ : Mesleki bağlılık boyutları derin davranışı pozitif yönde anlamlı olarak etkilemektedir.

$\mathbf{H}_{3}$ : Mesleki bağlılık boyutları samimi davranışı pozitif yönde anlamlı olarak etkilemektedir.

\section{BULGULAR VE TARTIŞMA}

Çalışmanın bu kısmında, örneklemden elde edilen verilerin çeşitli istatistiki yöntemlerle analiz edilmesi sonucu elde edilen bulgulara yer verilmiştir.

Araştırmada kullanılan ankette, örneklemin demografik özelliklerini ölçmek üzere altı madde bulunmaktadır. Bular; cinsiyet, medeni durum, yaş, akademik ünvan, çalışma süresi, ve gelirdir. Araştırmaya katılan akademisyenlerin \%42,5'i kadınlardan, \%57,5’i ise erkeklerden oluşmaktadır. Örneklemin çoğunluğu erkektir. Ayrıca yine \%61,2'lik bir oranla büyük bir çoğunluğun evli olduğu görülmektedir. Araştırmaya katılanların \%36,6'sı 30-39 yaşları arasında sadece \%1,5'i ise 60 ve üzeri olduğu görülmektedir. Katılımcıların Çoğunluğu araştırma görevlilerinden oluşmaktadır. Toplamın \%32,2'sini oluşturmaktadırlar. Çalışma sürelerine bakıldığında 
ise \%8,8'i 1 yıldan az, \%29,3'ü 1-5 yıl, \%16,5'i 6-10 yıl, \%27,8'i 11-20 yıl, \%17,16'sı 21 ve üzeri zamandır bir iş yerinde çalışıyor oldukları görülmektedir.

Duygusal Emek Ölçeği Faktör Analizi: Ölçeğin geçerliliğini kanıtlamak amacıyla yapılan açıklayıcı faktör analizi sonucunda Kaiser-Olkin-Mayer (KMO) değerinin 0,85 olduğu tespit edilmiştir. Bu değerin 0,5'in üstünde olması örneklem büyüklüğünün faktör analizi için uygun olduğunu göstermektedir. Aynı şekilde, Bartlett küresellik testi (Yaklaşık =1537,031; SD=91) değeri de 0,000 düzeyinde anlamlı olarak hesaplanmıştır. Bu da verilerin faktör analizine uygun olduğunu doğrulamaktadır. Analiz sonucunda düşük faktör yüklerine sahip olan ve iki faktöre yüklenen ifadeler analizden çıkarılarak kalan 13 ifade ile değerlendirmeler gerçekleştirilmiştir. Faktör analizi sonucunda, 1. faktör varyansın \% 31,609'unu, 2. faktör \%19,241'ini ve 3. faktör \%12,272'sini açıkladığı tespit edilmiştir. Ölçeğin Duygusal emeği üç faktörlü olarak açıklama düzeyi ise \%63,022 dir. Ölçekteki faktörlerin güvenilirlik (iç tutarlılık) katsayıları ise sırasıyla; yüzeysel davranış: 0, 851, derinlemesine davranış: 0, 777 ve samimi davranış: 0, 715 olarak bulunmuştur.

Mesleki Bağlılık Ölçeği Faktör Analizi: Ölçeğin geçerliliğini kanıtlamak amacıyla yapılan açıklayıcı faktör analizi sonucunda Kaiser-Olkin-Mayer (KMO) değerinin 0,76 olduğu tespit edilmiştir. Bu değerin 0,5'in üstünde olması örneklem büyüklüğünün faktör analizi için uygun olduğunu göstermektedir. Aynı şekilde, Bartlett küresellik testi (Yaklaşık =1160,617; SD=45) değeri de 0,000 düzeyinde anlamlı olarak hesaplanmıştır. Bu da verilerin faktör analizine uygun olduğunu doğrulamaktadır. Analiz sonucunda düşük faktör yüklerine sahip olan ve iki faktöre yüklenen ifadeler analizden çıkarılarak kalan 10 ifade ile değerlendirmeler gerçekleştirilmiştir. Faktör analiz sonucunda, 1. faktör varyansın \%27,257'sini, 2. faktör \%27,187'sini ve 3. faktör \%16,698'ini açıkladığı tespit edilmiştir. Ölçekteki faktörlerin güvenilirlik (iç tutarlıık) katsayıları ise sırasıyla; mesleki duygusal bağlılık: 0,777, mesleki devam bağlılığı: 0,839 ve normatif bağlılık: 0,842 olarak bulunmuştur.

Bu çalışmada kullanılan değişkenlerin boyutları arasındaki ilişkileri belirleyebilmek amacıyla korelasyon analizi yapılmıştır. Bu bağlamda, duygusal emek boyutlarından olan yüzeysel, derinlemesine ve samimi davranış boyutlarının mesleki bağlılık boyutlarından duygusal bağlık, devam bağlılığı ve normatif bağlılık ile ilişkilerini gösteren korelasyon matrisi Tablo 1'te gösterilmektedir.

Tablo 1: Betimsel İstatistik Değerleri ve Korelasyon Analizi Sonuçları

\begin{tabular}{llllllllll}
\hline & $\mathrm{N}$ & Ort. & S.S & 1 & 2 & 3 & 4 & 5 & 6 \\
\hline $\begin{array}{l}\text { Yüzeysel } \\
\text { Davranış(1) }\end{array}$ & 273 & 2,0348 & 0,748 & 1 &, $432^{* *}$ &,$-172^{* *}$ &,$-099^{* *}$ &, $641^{* *}$ &, $154^{* *}$ \\
$\begin{array}{l}\text { Derin } \\
\text { Davranış(2) }\end{array}$ & 273 & 2,3324 & 0,880 & 1 &, 053 &, 092 &, $617^{* *}$ &, 072 \\
$\begin{array}{l}\text { Samimi } \\
\text { Davranış(3) }\end{array}$ & 273 & 4,2253 & 0,846 & & 1 &, $302^{* *}$ &, 035 &,-051 \\
$\begin{array}{l}\text { Duygusal } \\
\text { Bağ|ılık(4) }\end{array}$ & 273 & 2,5778 & 0,843 & & & 1 &, 038 &, $127^{* *}$ \\
$\begin{array}{l}\text { Normatif } \\
\text { Bağlılık(5) }\end{array}$ & 273 & 3,5485 & 0,987 & & & & 1 &, 106 \\
$\begin{array}{l}\text { Devam } \\
\text { Bağlılığı(6) }\end{array}$ & 273 & 4,1941 & 0,630 & & & & & & 1 \\
\hline
\end{tabular}

** Korelasyon değerleri 0.01 düzeyinde anlamlıdır.

Tablo 1 incelendiğinde yüzeysel davranışın normatif bağ|ılık（ $r=0,641, \quad p<0,01)$ ve devam bağ|ılığı（ $r=0,154$, $\mathrm{p}<0,01)$ ile pozitif yönde, duygusal bağlılık ( $r=-0,099, \quad \mathrm{p}<0,01)$ ile negatif yönde ilişkisinin olduğu görülmektedir. Yani yüzeysel davranış göstermek normatif bağlılık ve mesleki bağlılığı yükseltirken, duygusal bağlıı̆̆ı azaltmaktadır. Duygusal emeğin ikinci boyutu olan derin davranışın ise mesleki bağlılık boyutlarında sadece normatif bağlılık $(r=0,617, \quad \mathrm{p}<0,01)$ ile pozitif yönde bir ilişkisi olduğu görülmektedir. Yani, bireyler derin davranış sergiledikçe mesleklerine duydukları normatif bağlılık artacaktır. Sami davranış ise sadece 
duygusal bağlılık $(r=0,302, \quad p<0,01)$ ile pozitif yönde ilişki içindedir. Bu durumda bireylerin duygusal bağ|ılığı arttıkça daha fazla samimi davranış sergileyeceklerini ifade etmektedir.

Duygusal emek boyutlarının mesleki bağlılık boyutları üzerindeki etkisini belirleyebilmek için üç regresyon modeli kurularak araştırma doğrultusunda belirlenen hipotezler $\left(\mathrm{H}_{1}, \mathrm{H}_{2}, \mathrm{H}_{3}\right)$ test edilmiştir.

Tablo 2: Yüzeysel Davranış ve Mesleki Bağlılık Boyutları Arasındaki Etkileşimi İnceleyen Çoklu Regresyon Analizi

\begin{tabular}{|l|l|l|l|}
\hline BAĞıMSIZ DEĞiŞKENLER & BETA & T & SiG. (P) \\
\hline Duygusal Bağlıık & $-0,137^{*}$ & $-2,95$ & 0,003 \\
\hline Normatif Bağlıık & $0,635^{* *}$ & 13,78 & 0,000 \\
\hline Devam Bağlılı̆̆ı & $0,104^{*}$ & 2,24 & 0,026 \\
\hline F & 69,39 & \\
\hline $\mathbf{R}^{\mathbf{2}}$ &, $436^{* *}$ \\
\hline Bağımlı Değişken: Yüzeysel Davranış \\
\hline
\end{tabular}

* Değer 0,05 düzeyinde anlamlıdır ** Değer 0,01 düzeyinde anlamlıdır

Analiz sonuçlarına bakıldığında model anlamlı çıkmıştır. $\beta$ değerlerine baktığımızda duygusal bağlılığın $(\beta=-0,137$, $\mathrm{p}<0,05)$ yüzeysel davranışı negatif yönde, anlamlı olarak etkilediği görülmektedir. Diğer bir ifadeyle duygusal bağlılıktaki bir birimlik artış yüzeysel davranış gösterimde 0,137'lik bir azalışa neden olmaktadır. Normatif bağlılık $(\beta=0,635, p<0,01)$ ve devam bağlılığı $(\beta=0,104, p<0,05)$ ise yüzeysel davranışı pozitif yönde anlamlı olarak etkilemektedir. Sonuçlara göre $\mathrm{H}_{1}$ hipotezi desteklenmektedir. Tablo 2'deki R kare değerine bakıldığında mesleki bağlılık boyutlarının (Duygusal, Devam ve Normatif Bağlılı̆̆ı) yüzeysel davranış göstermede önemli bir etkisinin olduğunu görülmektedir $\left(R^{2}=\% 43\right)$. Yani, yüzeysel davranış gösteriminde \%43 oranında mesleki bağlılık boyutları etkilidir.

Tablo 3: Derin Davranış Ve Mesleki Bağlılık Boyutları Arasında Etkileşimi İnceleyen Çoklu Regresyon Analizi Sonuçları

\begin{tabular}{|l|l|l|l|}
\hline BAĞıMSIZ DEĞişKENLER & BETA & T & SiG. (P) \\
\hline Duygusal Bağ|ılık & 0,068 & 1,41 & 0,159 \\
\hline Normatif Bağlıık & $0,615^{* *}$ & 12,78 & 0,000 \\
\hline Devam Bağ|ı̆ı̆ı & $-0,002$ & $-0,03$ & 0,969 \\
\hline F & 56,200 & \\
\hline $\mathbf{R}^{\mathbf{2}}$ &, $385^{* *}$ & \\
\hline Bağımlı Değiş̧ken: Derin Davranış &
\end{tabular}

* Değer 0,05 düzeyinde anlamlıdır ** Değer 0,01 düzeyinde anlamlıdır.

Analiz sonuçlarına göre model istastiki olarak anlamlı çıkmıştır. $\beta$ değerlerine baktığımızda sadece normatif bağlılığın $(\beta=0,615, p<0,01)$ derin davranışı anlamlı olarak etkilediği görülmektedir. Normatif bağlılıktaki bir birimlik artış derin davranış gösteriminde $0,615^{\prime}$ lik bir artışa neden olmaktadır. Bu sonuçlar doğrultusunda $\mathrm{H}_{2}$ hipotezi kısmen desteklenmektedir. Tablo 3'de yer alan sonuçlar derin davranıştaki değişimin \%38'inin $\left(R^{2}=0,385\right)$ mesleki bağlılık boyutları ile açıklandı̆̆ını göstermektedir. 
Tablo 4: Samimi Davranış Ve Mesleki Bağılıık Boyutları Arasındaki Etkileşimi İnceleyen Çoklu Regresyon Analizi Sonuçları

\begin{tabular}{|l|l|l|l|}
\hline BAĞıMSIZ DEĞiŞKENLER & BETA & T & SiG. (P) \\
\hline Duygusal Bağıııı & $0,312^{* *}$ & 5,35 & 0,000 \\
\hline Normatif Bağıııık & 0,032 & 0,55 & 0,578 \\
\hline Devam Bağ|ı̆ı̆̆ı & $-0,094$ & $-1,59$ & 0,112 \\
\hline F & 9,969 & \\
\hline $\mathbf{R}^{2}$ &, $100^{* *}$ \\
\hline Bağımlı Değişken: Samimi Davranış
\end{tabular}

* Değer 0,05 düzeyinde anlamlıdır ** Değer 0,01 düzeyinde anlamlıdır.

Analiz sonuçlarına göre model istastiki olarak anlamlı çıkmıştır. Tabloda 4'de yer alan sonuçlar samimi davranıştaki değişimin \%10'unun mesleki bağııık ile açıklandığını göstermektedir. Katsayılar tablosuna baktığımızda sadece samimi davranış ve duygusal bağıııı arasındaki etkileşim anlamlı çıkmışır. Diğer bir ifade ile mesleki bağııık boyutlarından sadece duygusal bağlıık $(\beta=0,312, p<0,01)$, samimi davranışı etkilemektedir. Duygusal bağılıktaki bir birimlik artış samimi davranış gösteriminde $0,312^{\prime}$ lik bir artışa neden olmaktadır. Bu sonuçlar doğrultusunda $\mathrm{H}_{3}$ hipotezi kısmen desteklenmektedir.

\section{SONUÇ}

Bu çalışmada, duygusal emek bağılı̆ğı ile mesleki bağlıık arasındaki ilişki ve mesleki bağ|ılığın duygusal emek gösterimindeki rolü açıklanmaya çalışılmışıı. Bu amaçla Türkiye'deki beş devlet üniversitesinde görev yapmakta olan akademisyenlerden elde edilen veriler üzerinde incelemeler yapılmıştır. Online anket uygulaması ile 273 akademisyenden elde edilen veriler faktör, korelasyon ve regresyon analizleri yapılarak değerlendirilmiştir. Faktör analizi sonucunda ölçeklerin geçerliliği kanıtlanmış ve literatüre benzer olarak hem duygusal emek (yüzeysel, derin ve samimi davranış) hem de mesleki bağlılık (duygusal, normatif ve devam bağ|ılığı) ölçekleri üç boyut altında toplanmıştır. Yapılan korelasyon analizi sonucunda ise değişkenler arasında anlamlı ilişkilerin olduğu belirlenmiştir. Hipotezleri test etmek için yapılan çoklu regresyon analizleri sonucunda ise;

$\checkmark$ mesleki bağlılık boyutlarından normatif bağlılık ve devam bağlılı̆ının pozitif, duygusal bağılı̆̆ın ise negatif yönde yüzeysel davranışı anlamlı olarak etkilediği,

$\checkmark$ mesleki bağlııık boyutlarından normatif bağılıı̆ın derin davranışı pozitif yönde anlamlı olarak etkilediği,

$\checkmark$ mesleki bağlıık boyutlarından duygusal bağııı̆ıı samimi davranışı pozitif yönde anlamlı olarak etkilediği tespit edilmiştir.

Elde edilen sonuçlar doğrultusunda $\mathrm{H}_{1}$ hipotezi desteklenirken, $\mathrm{H}_{2}$ ve $\mathrm{H}_{3}$ hipotezleri kısmen desteklenmiştir. Araştırma sonuçlarına bakıldığında akademisyenlerin mesleklerine karşı duydukları bağııık türlerinin duygusal emek gösterimleri üzerinde dikkate alınması gereken bir etkiye sahip olduğu görülmektedir. Normatif bağılığa ve devam bağılığına sahip olan akademisyenle daha fazla yüzeysel ve derin davranış gösteriminde bulunurken, duygusal bağlılığa sahip olan akademisyenler samimi davranış gösteriminde bulunmaktadırlar.

Literatürde duygusal emek ve mesleki bağlıık kavramlarının farklı değişkenler ile yoğun olarak çalışıldığı görülmektedir. Ancak duygusal emek ve mesleki bağılık arasındaki ilişkiyi incelen yeterli sayıda çalışma yoktur. Bu iki kavram arasındaki ilişkiyi ortaya koyan ilk çalışmanın Prentice (2012) tarafından yapıldığı söylenebilir. Catherine Prentice (2012)'de turizm ve eğlence sektörü üzerinde mesleki bağlıık, duygusal emek ve performans arasındaki ilişkiyi ve mesleki bağılığın duygusal emek ve performans arasındaki aracılık rolünü inceleyen bir araştırma gerçekleştirmiştir. Araştırma sonuçları duygusal emek boyutları ve mesleki bağlıık boyutları arasında anlamlı ilişkilerin olduğunu, aynı zamanda mesleki bağlıık boyutları olan duygusal bağ|ıık ve devam bağ|lığının duygusal emek stratejisini uygulamayı kolaylaştırarak performans çıktılarııı artırdığını ortaya koymuştur (Prentice, 2012; 1-6). Bu araştırma ile elde edilen sonuçlar da literatür ile paralellik göstermektedir. 
Araştırma zaman ve maddi kısıtlar nedeniyle katılımcıların doğru cevapladığı varsayılarak online olarak yapılmıştır. Bu konu ile ilgi yeni çalışmalar ortaya koyacak olan araştırmacılara sonuçların genellenebilirliğini arttırmak için daha fazla katılımcıya ulaşmaları ve verileri yüz yüze toplamaları tavsiye edilmektedir. Ayrıca, henüz bu iki değişken arasındaki etkileşimi inceleyen çok az çalışma olması nedeniyle, araştırmanın farklı sektörlerde farklı meslek gruplarında tekrarlanması literatüre katkı sağlayacaktır. Yapılan çalışmalar sonucunda, duygusal emek ve mesleki bağlılık arasında güçlü bir ilişkinin olduğunu söyleyebiliriz. Bu nedenle, bu ilişkiye aracılık eden değişkenlerin araştırılması önerilmektedir.

\section{KAYNAKLAR}

Aranya, N., Pollock, J. \& Amernic, J. 1981, "An Examination Of Professional Committment in Public Accounting", Accounting, Organizations And Society, vol. 6, no. 4, pp. 271-280.

Ashforth, E.B. \& Humphrey, H.R. 1993, "Emotionallabor in service roles: The influence of identity", Academy of Management Review, vol. 18 , no. 1 , pp. $88-115$

Başbuğ, G., Ballı, E. \& Oktuğ, Z. 2010, “Duygusal Emeğin İş Memnuniyetine Etkisi: Çağrı Merkezi Çalışanlarına Yönelik Bir Çalışma”, Sosyal Siyaset Konferansları Dergisi, vol. 58, 254-274.

Baysal, A.C. \& Paksoy, M. 1999, “ Mesleğe Ve Örgütte Bağlılı̆̆ın Çok Yönlü İncelenmesinde Meyer-Allen Modeli”, İstanbul Üniversitesi işletme Fakültesi Dergisi, vol. 28, pp. 7-15.

Beğenirbaş, M. \& Yalçın, R.C. 2012, "Öğretmenlerin Kişilik Özelliklerinin Duygusal Emek Gösterimlerine Etkileri”, Cag University Journal of Social Sciences, vol. 9, no. 1, pp. 47-66.

Brotheridge, C. \& Grandey, A. 2012, "Emotional Labor and Burnout: Comparing Two Perspectives of People Work", Journal of Vocational Behavior, vol. 60, pp. 17-39.

Brotheridge, C.M. \& Grandey, A.A. 2002, "Emotional Labor And Burnout: Comparing Two Perspectives Of 'People Work", Journal Of Vocational Behavior, vol. 60, pp. 17-39.

Brotheridge, C.M. \& Lee, R. 1998, “On The Dimensionality Of Emotional Labor: Development And Validation Of An Emotional Labor Scale", Paper Presented At The First Conference on Emotions in Organizational Life, San Diego: Ca.

Chu, K. H. \& Murrmann S.K. 2006, "Development and Validation of the Hospitality Emotional Labor Scale", Tourism Management, vol. 27, no. 6, pp. 1181-1191.

Çetin, M., Cihangiroğlu, N. \& Türk, Y. Z. 2010, “Bir Grup Eczacının Mesleki Bağlılık Algılarının İncelenmesi”, Pamukkale Tıp Dergisi, vol. 3, no. 3, pp. 125-130.

Diefendorff, J.M. \& Gosserand, R.H. 2003, "Understanding The Emotional Labor Process: A Control Theory Perspective", Journal Of Organizational Behavior, vol. 24, pp. 945-959.

Grandey, A.A. 1999, "The Effects of Emotional Labor: Employee Attitudes,Stress and Performance", Yayınlanmamış Doktora Tezi, Colorado: Colorado State University, USA.

Grandey, A.A. 2000, "Emotion regulation in the workplace: A new way to conceptualize emotional labor", Journal of Occupational Health Psychology, vol. 5, no. 1, pp. 95-110.

Grandey, A.A. 2003, “When 'The Show Must Go On': Surface Acting And Deep Acting As Determinants Of Emotional Exhaustion And PeerRated Service Delivery”, Academy Of Management Journal, vol. 46, no. 1, pp. 86-96.

Hochschild, R.A. 1983, "The managed hearth: Commercialization of human feelings" Berkeley: University of California Pres.

Köksel, L. 2009, “iş̧ Yaşamında Duygusal Emek Ve Ampirik Bir Çalışma”, Celal Bayar Üniversitesi, Sosyal Bilimler Enstitüsü, İşletme Anabilim Dalı, Yönetim Organizasyon Programı, Manisa.

Kruml, S.M. \& Geddes, D. 2000, "Exploring The Dimensions Of Emotional Labor: The Heart Of Hochschild's Work", Management Communication Quarterly, vol. 14, no. 8, pp. 8-49.

Lee, K., Carswell, J.J. \& Allen, N.J. 2000, "A Meta-Analytic Review Of Occupational Commitment :Relation With Person And Work-Related Variables", Journal Of Applied Psychology, vol. 85, pp. 799-811.

Meyer, J.P., Allen, N.J. \& Smith, C.A. 1993, “Commitment To Organizations And Occupations: Extension And Test Of A Three-Component Conceptualization", Journal Of Applied Psychology, vol. 78, pp. 538-551.

Morrow, P.C. 1983, "Concept Redundancy in Organizational Research: The Case Of Work Commitment", The Academy Of Management Review, vol. 8, no. 3, pp. 486-500.

Morrow, P.C. 1993, "The Theory And Measurement Of Work Commitment", Greenwich, Jai Press. 
Oral, L. \& Köse S. 2011, “Hekimlerin Duygusal Emek Kullanımı ile iş̧ Doyumu ve Tükenmişlik Düzeyleri Arasındaki iliş̧kiler Üzerine Bir Araştırma”, Süleyman Demirel Üniversitesi, iktisadi ve Idari Bilimler Fakültesi Dergisi, cilt. 16, sayı. 2, ss. 463-492.

Özdevecioğlu, M. \& Aktaş, A. 2007, “ Kariyer Bağlılığının, Mesleki Bağlılık Ve Örgütsel Bağlılığın Yaşam Tatmini Üzerindeki Etkisi: İş-Aile Çatışmasının Rolü”, Erciyes Üniversitesi Iktisadi Ve Idari Bilimler Fakültesi Dergisi, Sayı:28, ss. 1-20.

Özgen, I. 2010, "Turizm İşletmelerinde Duygusal Emek", Ankara, Detay Yayıncılık.

Prentice, C. 2012, "The Influence Of Occupational Commitment On Emotional Labour", Australian And New Zealand Marketing Academy And Ehrenberg-Bass Institute For Marketing Science, Edith Cowan University, pp. 1-6.

Tak, B. \& Çiftçioğlu, A. 2009, “Üç Boyutlu Mesleki Bağlılık Ölçeğinin Türkçe'de Güvenilirlik Ve Geçerliliğinin İncelenmesine Yönelik Bir Alan Araştırması”, İ̧̧letme Fakültesi Dergisi, Cilt. 10, Sayı. 1, ss. 35-54. 